\title{
Technology and technology policy in the postwar UK : « market failure » or « network failure » ?
}

\section{Nick von Tunzelmann}

\section{(2) OpenEdition \\ 1 Journals}

Édition électronique

URL : https://journals.openedition.org/rei/4157

DOI : 10.4000/rei.4157

ISSN : $1773-0198$

Éditeur

De Boeck Supérieur

Édition imprimée

Date de publication : 15 juin 2010

Pagination : 237-258

ISSN : 0154-3229

\section{Référence électronique}

Nick von Tunzelmann, «Technology and technology policy in the postwar UK : « market failure » or

« network failure »? », Revue d'économie industrielle [En ligne], 129-130 | 1er et 2e trimestres 2010, document 10, mis en ligne le 15 juin 2012, consulté le 03 juin 2022. URL : http://

journals.openedition.org/rei/4157 ; DOI : https://doi.org/10.4000/rei.4157 


\section{TECHNOLOGY AND TECHNOLOGY POLICY IN THE POSTWAR UK: «MARKET FAILURE » $\mathrm{OR} \ll$ NETWORK FAILURE »?}

Mots-clés : Défaillances de marché, défaillances de réseaux, technologie, politique technologique britannique, apprentissage

Key words: Market Failures, Networks Failures, Technology, British technology policy, Learning

\section{INTRODUCTION}

The principal argument that has been developed in many countries for supporting important government activities in the arena of Science and Technology (S\&T) emerges from notions of « market failure »- left to themselves, markets would not allocate sufficient resources to the advancement of S\&T from an economic and social point of view.

More precisely, an extensive literature in economics that dates back at least to the classic studies by Nelson (1959) and Arrow (1962), later refined by the « new growth » theorists like Romer $(1986,1990,1994)$, has contended that markets will under-invest in R\&D when there is: a) incomplete appropriability (« non-excludability») - that is, firms cannot keep all the benefits of their research to themselves, as knowledge leaks out to others; b) non-depletability ( « non-rivalry ») - i.e. the results of R\&D can be used by others without incurring real resource costs. However, in practice, the costs of imitation may be much higher than implied by the new growth theorists, casting doubt on the free-lunch nature of any technological « spillovers ».

Section 1 of this paper begins by looking at how the case for government intervention via technology policy in the UK in the later $20^{\text {th }}$ century was typically justified by «market failure » arguments, and goes on in more analytical vein to contrast these with a view that would play up non-market sources of failure. Section 2 summarises some of my earlier work in the economic histo- 
ry of the postwar UK (von Tunzelmann, 2003), here updated, to contend that an analysis of technology trends indicates that non-market failures, mainly systemic and dynamic in nature, were a more basic source of British technological shortcomings in this period (and probably in most other leading countries of the time). In section 3, analysis of the trends in technology policy suggests that narrowly economics-based views too often hampered good intentions to reform policy along more appropriate lines, and restricted development of adequate capabilities for «policy learning ». Section 4 consists of a discussion of policy learning in a context of network misalignment and systemic failure, while section 5 draws some conclusions intended to achieve more satisfactory policy designs. The core analytical perspective adopted throughout the paper can be seen as representing an application of the RichardsonSen model(s) of capabilities and networking to the government/policy-making field (cf. Richardson, 1972, 2008; Sen, 1985).

\section{I. - MARKET FAILURES VERSUS NON-MARKET FAILURES}

According to Barber and White (1987), the chief forms of «market failure » invoked by policy-makers in the UK government department responsible in the mid-1980s for technology policy - the Department of Trade and Industry (DTI) - were as follows :

i) Risk - firms were too often risk-averse to carry out R\&D projects, even when they stood a good chance of succeeding;

ii) Information - asymmetries of access to relevant technological information existed, especially for small and medium-sized enterprises (SMEs);

iii) Competition and market structure meant that high $R \& D$ costs often acted as entry barriers against newer entrants;

iv) Externalities - especially the non-appropriable benefits from spillovers to competitors;

v) «Dynamic » elements, as these writers term them - particularly secular changes such as « infant industry » and « infant technology » situations.

Barber and White stress that such a list was incomplete from a theoretical viewpoint, and indeed that policy-makers did little to interact with economic theory (it should be noted that John Barber was at the time and until his recent retirement employed by the DTI). But how appropriate was contemporary theory in any case to the growing emphasis in policy (and practice) of collaborative research/R\&D (a pattern to be described below)?

The principal claim made in this paper is that many of the «failures » that have been in operation in the actual British context in the postwar years have been «non-market failures » rather than the above (or more extended) list of market failures, and in addition that many of the presumed market failures as 
TABLE 1 : Modes of governance and forms of failure

\begin{tabular}{|l|l|l|l|}
\hline Governance mode & & Form of failure & \\
Markets & Invisible hand & Market failure & Trembling hand \\
\hline Hierarchies - corporate & Visible hand & Corporate failure & \\
\hline Hierarchies - government & & Government failure & Grabbing hand \\
\hline Networks & Greeting hand & Network failure & Shaking hand \\
\hline
\end{tabular}

diagnosed in reality concealed deeper «non-market failures ». Hence our first task is to attempt a categorization of « non-market failures », whose character might appear less immediately apparent. To do so, failures as well as « successes » can be related to each main type of governance mode. For present purposes, the economical definition of « governance » provided by Prakash and Hart (1999) is taken as adequate - governance is " organizing collective action ».

The literature seems to recognise four main modes of governance, namely markets, hierarchies - of two kinds, corporate and government - and networks (e.g. Thompson et al., 1991). For present purposes, I define «networks » in a residual and somewhat negative way, namely all interactions between or among agents that do not involve power relations or market exchanges. To each mode there corresponds a particular form of failure, and both the mode and its negation in the associated form of failure is frequently classified as a kind of « hand », in tribute to Adam Smith's « invisible hand » to describe the market mode (see table 1).

The broad category of «non-market failures » thus encompasses failures that are hierarchical (both corporate and government, i.e. in both the private and public sectors) or networked in form. Most of our attention in what follows will in fact be directed at the «network failures », partly because these are the least familiar in the literature, but more because they often in practice encapsulate aspects of all the other forms of failure. The nature of networks and of the associated « network failure » will be examined at some length below.

Since the concept of «non-market failure » may seem somewhat abstract, Table 2 provides a list of a handful of illustrative examples. The forms of fai-

TABLE 2 : Specific (individual) vs. systemic failures

\begin{tabular}{|l|l|l|}
\hline Governance mode & Specific failures (examples) & Systemic failures (examples) \\
\hline Market & Product under/over-supply & Shortage economy \\
\hline Corporate & Company bankruptcy & Poor organizational systems \\
\hline Government & Corrupt ministers & Central planning \\
\hline Network & Too few/many members & Network misalignment \\
\hline
\end{tabular}


lure in each mode are divided into « specific » (individual) cases, of a failure in one market (etc.), as against « systemic failures », consisting of failures in multiple (or all) markets (etc.). « Network failures » are often identified with « systemic failures », but we consider that there is merit in conceptually distinguishing the two, with network failures constituting a row item in this table, while systemic failures are a column item, with instances that can be associated with each mode of governance (the table follows a similar one given in Larsen and von Tunzelmann, 2008, except that in the English-language version of that paper we referred to specific failures as « intrinsic »).

Thus for the orthodox market mode of governance, an under-supply or else an over-supply of a product in a particular market, relative to demand (given the prevailing price) - say in the market for petroleum - constitutes a « specific failure ». The macro version of this could be the « shortage economy » as described by Kornai (1980) for the Central and Eastern European economies in the communist era, reflecting a generalised absence of goods on the shelves of shops in the "marketplace ». However in both cases one would expect the duration of such disequilibria to be short owing to the presumed operation of conventional Walrasian price dynamics (1) - unless the disequilibrium is underpinned by political (i.e. governmental) or other (e.g. monopolistic corporate) forces arising out of other forms of "failure ». As will be seen in a moment, this is precisely the point to drive home here. Other forms of market failure that are less open to Walrasian pressures would include problems arising out of the potential for confusion between the « low quality » and « good bargain » signals of low prices, as in the celebrated Akerlof (1970) model of the market for « lemons » (poor quality automobiles), and the general ArrowDebreu problem of the absence in reality of the full set of contingent and future markets required for the invisible hand property to function.

For the other modes of governance, the distinction between specific (intrinsic) and systemic failures can be built up in parallel fashion. Thus corporate failure can be regarded as the failure of individual companies (say Enron or Lehman Brothers) at a specific level, or a more generalised inability to attend to corporate structures (as for instance Chandler et al., 1999, allege of British companies being slow to embrace multidivisional organisation in the first half of the $20^{\text {th }}$ century - see section 2.4 below) at a systemic level. Similarly government failures can arise from corruption in a particular ministry (specific), or more widespread weaknesses of the political system (as for example under Soviet-style central planning - systemic). In both cases there may be intermediate situations of chain reactions of failure that spread across a number of corporations or government departments, while stopping short of general (fully systemic) failure; in which case network issues might well have arisen. The examples of specific network failure chosen for illustration in the

(1) I owe an emphasis on this point to remarks by Richard Arena at the workshop. 
table, however, concern situations where the network consists of too few members (lacking « density »), or perhaps too many to operate effectively. The systemic case of «network alignment» will be entertained below. Roughly speaking, « specific failures » correspond to the economic context of «partial disequilibrium », whereas « systemic failures » correspond to " general disequilibrium »; though with the source of disequilibrium varying depending on the agent involved (corporation, etc.).

It needs to be stressed that, in practice, few if any significant real-world situations reflect a unique mode of governance, but our theoretical models for dealing with complexity in governance (like conjoined corporate and government modes or forms of failure) are practically non-existent. This is most evident for the case of networks, few of which in reality do not involve additional elements of power relations or of monetary exchange, though not necessarily all at the same time.

All of us are involved in multiple networks, as a measure of the complexity we face - networks of academic disciplines, of work-based organizations, of policy-makers, of kinship, etc. We can thus think of «networks of networks », for each individual agent - and individuals come together to form organizations and institutions, as compound agents. Just like other forms of governance, networks are subject to «failure » (as in table 2), and these network failures can involve:

a) a required network being missing or very ineffective (specific failure, as studied in much « social network analysis »);

b) an existing set of networks that pursue antisocial targets (systemic failure in goals);

c) an existing set of networks that pursue socially acceptable targets but in inconsistent ways (systemic failure in instruments).

Of these, the third type is the most elusive but probably the most important. They generate issues that are being studied by the " network alignment " approach. Thus in my Revue d'Économie Industrielle paper of 2004, I paid particular attention to the mismatch between the EU's macroeconomic policy, as a restrictive set of policies under the flag of the Stability and Growth Pact and the associated Maastricht criteria, and its technology policy, as a set of expansionist policies grouped around the Lisbon Agenda of 2000 and the associated Barcelona target of raising the rate of GERD intensity to $3 \%$ of national income. While two-thirds of the supposed $3 \%$ target was supposed to come - somehow - from the private sector, it was, and still remains, difficult to see how such an expansionary rise in $R \& D$ could come about in a constrictive macroeconomic environment. To account for the network dimensions of this issue however requires some further consideration be given to the nature of the relevant «system ». 
The kinds of systems that are indeed relevant here are the " techno-economic systems » portrayed by Freeman and colleagues (e.g. Freeman and Perez, 1988; Lee and von Tunzelmann, 2005). The evolution of such techno-economic systems over the longer term has been driven by:

a) technical drivers on the supply side;

b) economic drivers on the demand side;

c) the interfaces between the technical and economic drivers; and

d) cross-currents of « complexity », that are i) spatial, especially globalization, ii) functional, especially new technologies.

Networks are offered as a generic solution to the emerging problems of such complexity, because they enable appropriate linkages to be made, especially where the context of «networks of networks » can thrive. "Pure » networks, involving as already stated interchanges among agents that do not (principally) concern power or market relations, arise most often in situations of exchanges of knowledge. This occurs because of the combinatorial properties of much knowledge (i.e. joining rather than supplanting, or complementary rather than competitive), together with the difficulties of valuing knowledge in markets.

The network alignment approach accepts this « solution » to many contexts of complexity, but does not find it unproblematic. Among the problems that the resort to networks throws up are the following (this list is by no means exhaustive) :

a) practical problems of managing and organizing networks - contrary to much of the literature such networks do not simply organize and manage themselves, and the absence of a hierarchical or market mode of governance actually intensifies the problems to be dealt with, especially in the common context of « networks of networks », where a given network organizer is likely to be managing one or two of the relevant networks while being managed in regard to the others. Building the trust and reciprocity normally required in a situation where overt power relations are ostensibly limited or non-existent calls for the exercise of tact, care and wisdom. Nevertheless the concern in this paper is with more analytical issues, which in part are responsible for the problems of managing networks ;

b) measuring knowledge, as the likely content of what the network interchanges - there are well-known limitations of the data extracted from such sources as innovation surveys, patents, $\mathrm{R} \& \mathrm{D}$, or skills as guides to assessing the effectiveness of the networks in question; to say nothing of the problems involved in trying to gauge tacit knowledge, absorptive capacity, etc. (Giuliani, 2007) ; 
c) assessing the network goals (targets) immediately runs into problems of overlapping and often conflicting goals for each agent in the network; for instance for firms (where the goals may be variously market-seeking, cost-seeking, or knowledge-seeking), for universities and other higher education institutes (goals may be to expand research, teaching, or revenues, say via IPRs etc.), for governments (political goals of a regulatory, developmental, or distributive nature), and so on. Problems of making these compatible in multiagent networks are of course often very serious ;

d) measuring network capabilities - matching " network structures » and knowledge structures (the instruments to achieve such conflicting goals, for knowledge creation, dissemination or interaction, e.g. through bridging institutions). Again the problems accumulate in multi-agent environments, e.g. for the higher education sector, which is expected to supply science and technology to firms but also some policy advice to governments ;

e) assessing the dynamics of knowledge accumulation - attaining the dynamic economies of scale and scope (increasing returns) involved in recompensing the system for the burdens imposed by networking. These are likely to involve time-saving and space-saving effects (issues of « when » and « where », to add to the usual list of « what », « how », « who » and « why »).

The complete attainment of «network alignment » is an improbability, given the multiplicity of goals, instruments, agents and networks involved. It is quite likely to be undesirable to reach any such optimum, because the costs of striving for perfection at the margin may well exceed the benefits. Nevertheless, at the heavily infra-marginal level at which most existing network structures probably operate, there is often much to be said in favour of aiming to do better - rather than achieving « best practice » I would thus follow evolutionary thinking in advocating the objective of « better practice».

It is time to confront these analytical propositions with the achievements and shortcomings of technology policy in the UK in the second half of the $20^{\text {th }}$ century.

\section{II. - THE POSTWAR UK RECORD IN TECHNOLOGY PERFORMANCE}

\subsection{Introduction}

The most evident change in governance over the period - in the UK as in many other leading countries - was the shift in its main thrust from being primarily government-led in the 1950 s and 1960 s to being primarily market-led in the 1970s and especially 1980s. Although the 1980s was associated with the pro-market Thatcher regime, these patterns were shared by both Labour and Conservative administrations. These were followed in turn by a more mixed 
set of views giving greater emphasis to collaboration in the 1990s, with decentralization in the most recent decade, reversing the somewhat inconsistent Thatcher trend towards increased centralization.

The major shift of emphasis in 1970s/80s implied that government technology projects then had to justify themselves using « market-failure » or at least « market-friendly » criteria. This went alongside a rather curious loss of popular faith in the properties of technology to redeem growth performance, which arose (at least in part) for the following reasons:

i) a continuing loss of British competitiveness in 1960s/70s in what were regarded as technology-based industries;

ii) a sequence of public relations disasters, e.g. nuclear power, and later BSE ( mad cow disease »), for which the government was perhaps only partly to blame (Henderson, 1977; van Zwanenberg and Millstone, 2005);

iii) many high-tech companies turned into financial flops, i.e. became specific corporate failures, particularly as the dot.com bubble burst in the early years of the present century, though with a considerable number of predecessors, like ICL in computers.

The correspondence between such loss of public respect for technology and an intensified desire by the UK government to obtain « market-friendly » outcomes led to a partial withdrawal of government support for technological objectives, after a high-water mark in the early 1980s. The consequences will be expanded on below, after giving some brief attention to the UK's track record in technological performance.

\subsection{Biases in technological change}

The main emphasis in the 1950s/60s was laid on capital-embodied technical progress, partly as a matter of reconstruction after the Second World War, but relying principally on the heavy and chemical industries of the preceding « Second Industrial Revolution » (coal-based electrification, steel, automobiles, heavy engineering, bulk chemicals, etc.). The focus for government support (either direct or indirect) thus lay on large capital-intensive firms like GEC or ICI, and in particular to support their efforts towards monopolization of their respective industries. At the meso-level, the focus on the consolidation of capital-intensive industries was intended to produce «national champions ». This phase coincided with an era of rising capital expenditure as a proportion of GDP, not just in the UK but across Western Europe more generally (for data and graphs, see von Tunzelmann, $1999: 28$ ). However the competition in such sectors spread across continents, with the rising «tigers » of Japan and a little later South Korea also targeting the heavy and chemical industries at this time. Moreover growing integration among the economies of Western Europe began to make the strategy of «national champions » look obsolete. 
Government policy, still framed largely in a national context, was slow to perceive any change of emphasis. It moved a little quicker into the newly emerging sectors like those based around IT, yet still for the most part retaining an assumption of the need for capital intensity and nationalistic fervour. In practice, the rising intensity of gross capital formation that persisted until about 1973 (2) gave way to a period in which investment rates fell. This fall in physical capital formation was partly offset by rising investment in $R \& D$, although the measures used for the latter (Frascati Manual definitions) reduced its magnitude, as compared with some broader notion of « intellectual capital ».

Associated with the shift from physical to intellectual capital was a shift in technological bias from to « embodied » to « disembodied » technical change, i.e. to technical change that was not so much embodied in capital equipment (machinery etc.), although more « embodied » in people. This aspect too was only slowly reflected in changes in government policy. « Embodiment » in people rather than in capital was epitomised by the expansion of software development, constituting a rising share of total investment in information and communication technologies (ICTs), though for long the emerging « Third Industrial Revolution » was identified with the hardware aspects of technology, especially of the electronics industry. In terms of products rather than technologies, the " information » content of ICTs was largely identified with « knowledge »- grossly oversimplifying the processes of technological and market learning.

\subsection{S\&T performance and funding}

The data available for the UK from the end of World War II to about the mid1990s are collected and graphed in von Tunzelmann (2003), and the present summary will just survey and update these figures where necessary.

\subsubsection{R\&D performance - GERD, BERD and HERD}

Figures on $R \& D$ expenditures have become the most widely cited of national indicators pertaining to technological performance. The attempt to construct a narrow consensual definition through the OECD's Frascati Manual means that much developmental work aimed at the commercialisation of innovations is left out of the figure for R\&D. It is widely believed that the UK is stronger at « upstream » science and technology than at « downstream » adoption and diffusion, so if anything UK expenditures tend to overstate its relative international performance in technology. Figures of « R\&D intensity », i.e. GERD (Gross Expenditure on R\&D) relative to the country's GDP, suggest a rapid build-up to a plateau of around $2.3 \%$ from the late 1950 s to the early

(2) For the more developed European countries the average capital intensity reached a plateau through most of the 1960s, before heading more sharply downwards after 1973. 
90s, followed by some decline in the early 1990s. These figures suggest the UK as at best holding its level of R\&D intensity, though failing to match the longer-term rises experienced in comparable European economies like France and (West) Germany. Over the decade from 1995 to 2004, the average R\&D intensity in the UK had fallen to about $1.8 \%$, compared with $2.2 \%$ in France, $2.4 \%$ in Germany and $2.6 \%$ in the USA (figures from UK ONS database (3)).

In terms of BERD, i.e. business expenditure on $\mathrm{R} \& \mathrm{D}$, in the long run there is again basic stability - from the late 60s through to the late 80s BERD sticks at about $1.5 \%$ of GDP, before declining in the 90s, notwithstanding the (part-)privatization of many government laboratories like the Atomic Energy Authority. Again, the UK did relatively badly compared with its international rivals.

For the case of HERD as a percentage of GDP the story is very different here a positive performance by the UK not only features but almost dominates the picture. Until the cuts in university funding at the end of the 70s the contribution of UK higher education institutions to the country's R\&D was well below that in comparable countries. The cuts and the associated reorientation of university research towards applied objectives in order to secure nongovernmental funding more than doubled the HERD contribution to UK GDP during the $80 \mathrm{~s}$. By the mid-80s the UK ratios were in the same ball-park as its rivals, and by the mid-90s there was strong convergence among the major countries. It can reasonably be claimed that the UK was successful in steering its universities into industrially relevant research. As of 2006, R\&D performed by higher education (including the research councils) in the UK was half of that performed by the entire business sector (BERD), whereas in 1996 it had been little over one third as much (ONS data).

Thus the pattern observed for the UK is rather different from most industrially advanced countries - instead of a slowdown in government R\&D expenditure being more than offset by rising business expenditure, the UK witnessed a slowdown in business $R \& D$ expenditure, perhaps even a fall, and a rise in higher education $R \& D$ that was offset by a fall in government expenditure in other domains.

\subsection{2. $R \& D$ funding}

These figures on expenditures, reflecting amounts performed by the respective agents, must be clearly differentiated from the sources of funding. In most countries, and the UK is no exception, the government funds considerably more R\&D than it performs. For instance, industrial funding was under onequarter of total R\&D in the mid-50s, but industry still did most of the performing (Gummett, 1991). In 1996 private business in the UK funded about $47 \%$ 
of total domestic R\&D but performed about $75 \%$ (Diederen et al., 1999). By 2006, the respective proportions were $45 \%$ and $62 \%$ (ONS data). In the UK most of this « subsidy » to industry has reflected military R\&D, where the government contracts out a substantial portion of defence-related $R \& D$.

Large changes occurred during the 1980s and early 90s. At the beginning of the 1980s government funded around half of the total R\&D performed in the country, but from 1983 this share dropped away (Georghiou, 2001). Industry's share rose from just over $40 \%$ in 1981 to a maximum about 10 points higher in 1988. Some part of the falling government share was compensated by a rising share funded by foreign sources, i.e. by increasing reliance on foreignbased multinational companies, and by other national sources (e.g. charities), especially after 1988. Charities were especially important in funding basic scientific research.

Overall the experiment of cutting UK government spending on R\&D in the hope of boosting private R\&D can hardly be judged a success. The growth in the UK R\&D stock was the slowest of the G6 countries 1972/89 and especially in 1990/4 (Buxton et al., 1998 : 172).

\subsubsection{Patenting}

Patent figures are regularly, though sometimes inadvisably, used as a measure of the output of technology. Most scholars are prepared to use them to gauge trends through time, if used with due care. The data for patents in the USA, chosen because it is the largest world market, relative to other advanced countries apart from the US, show UK patenting as declining in most periods from the 1880s onwards (when the data begin), except for the interwar period (Pavitt, 1980 : 38-44). After World War II the US patents data show Germany with a sustained increase almost throughout in per capita terms, reaching its peak just before German reunification in 1990. Having overtaken the UK in the late 1950s, at its peak the German level was about two and a half times that of the UK. France shows a slower rate of increase but still caught the UK by the early 1980s and rose somewhat above in the early 90s. The UK instead shows only a very slow trend increase in US patents per capita, reaching its peak in the early 1970s. All of these patterns are in fact dwarfed by Japan, which had dramatic rates of growth of US patenting over these years.

Alternative series are available for patenting at the European Patent Office (EPO) from the early 1980s. For the most recent years for which data are available (1995-2003) the average annual number granted to UK patentees was 112 (per million capita), compared with 127 for France, 149 for the USA, and 266 for Germany. Though this figure rose by $49 \%$ between 1995 and 2003 for the UK, the percentage increases were somewhat greater for these three comparator countries (ONS data). To the extent that patents do provide some indication of technological « output », the data give little comfort to the view of a strong UK performance. 


\subsubsection{Science - publications and citations}

As a guide to the underlying strength of technology, the growth of the science base is an obvious pointer. Using data from the Science Citations Index for $1981 / 2000$, the UK shares of both papers and citations thereto remain at respectably high levels, despite the global spread of science.

Overall, the numbers of publications when compared to the material covered above appear to indicate a much healthier state of British science than of British technology throughout the periods for which we have reasonable data. A government report in 1997 showed the UK carrying out $5.5 \%$ of the total world's research effort, producing $8.0 \%$ of the world's publications and $9.1 \%$ of all citations (May, 1997; Diederen et al., 1999). The Office of Science \& Technology thus showed a high « productivity » of British science in terms of papers per amount spent on science, although it can be doubted whether like was being compared with like. Even if valid, to many this simply reflected the low amounts spent in the denominator rather than the high outputs achieved in the numerator of the productivity calculation (Georghiou, 2001). The data do at the same time make the government attempts in the 1980s and early 90 s to blame universities rather than industry for Britain's economic woes rather implausible.

By the 1980s research funding had reached a stage which John Ziman captured in the title of the report, Science in a « Steady State » (1987). The report contrasted the sustained growth in science funding of preceding decades with the levelling off of the 1980s, which he considered would continue. At the same time the need for science showed no sign of levelling off, and the costs of undertaking science were also on the rise. How could this situation be squared? Industry and government implored academia to adopt more business-like methods, which were partly pursued; but to critics within academia this was imposing on them the methods of a more dubious UK business system.

\subsection{5. "Hidden innovation»}

A series of reports emanating from NESTA (4) $(2006,2007,2008)$ have pointed out that « Historically, the UK has suffered from poor performance relative to its major competitors on traditional measures of innovation » (NESTA, $2007: 4$ ), for instance R\&D per capita, but better once what it calls measures of « hidden innovation » are taken into account. Sector-specific studies suggest the following indicators of such « hidden innovation » (inter alia):

i) «Innovation that is identical or similar to activities that are measured by traditional indicators, but which is excluded from measurement... »;

(4) The National Endowment for Science, Technology and the Arts. 
ii) «Innovation without a major scientific and technological basis, such as innovation in organisational forms or business methods... »;

iii) «Innovation created from the novel combination of existing technologies and processes...»;

iv) « Locally-developed, small-scale innovations that take place « under the radar'» (ibid.: 5).

As these reports argue, the over-emphasis on traditional indicators has led to a situation in which, " Consequently, policymakers have responded by incentivising $R \& D$, encouraging businesses to collaborate with universities and substantially increasing public investment in scientific research $»($ ibid.: 4), rather than promoting these sources flagged by due recognition of « hidden innovation ». However the belief that the UK is particularly distinguished by such hidden forms of innovation remains an article of faith.

\subsection{Determinants of private-sector technological accumulation}

The primary deficiency of the British economy in regard to its innovative performance - at least so far as the technological dimension is concerned over the years from the 1960s to the 1990s thus arose in relation to the private sector of industrial business. It is there that one must begin the search for sources of «failure », even if as already strongly implied the failure turns out to be systemic at heart. Several candidates have proven popular in this respect.

\subsubsection{Organizational/governance issues}

The claimed weaknesses of British forms of industrial organisation, governance and management have been detected in a number of ways, apart from allegations of sheer managerial incompetence that are hard to substantiate in terms of any aggregate impact. Since this paper has laid some store on governance issues, a brief consideration should be given to some of the arguments set out here.

a) Delayed introduction of the «M-form » (multi-divisional) corporate style - this was the view put forward by the business historian Alfred Chandler (in Chandler et al., 1999), that British firms clung too long to obsolete corporate structures such as the «U-form» (unitary), which were too unfocused for an era of multi-product companies selling their products to a variety of markets. However, while this may be a valid criticism of UK corporations in the early postwar years, in the days when large capital structures were dominant, the product-oriented multi-divisional form itself became too rigid for the ensuing years when companies came to be not just multi-product and multi-regional, but multi-technology (Granstrand et al., 1997). More specifically, the M-form could become a source of rigidity in a period when corporations were aiming to develop ICT-based systems. 
b) Short-termism through myopic decision-making systems (e.g. Patel and Pavitt, 1988) - this argument holds that UK companies were particularly prone to avoiding long-term strategic decisions such as those to invest in major new technologies, under the pressure of powerful financial capital interests together with voracious demands for dividends by their shareholders. Companies such as the electrical equipment firm GEC (General Electric Company) preferred at times to accumulate monetary savings and place them in the stock market rather than reorient themselves to the new era of ICTs.

c) The « market for corporate control »- such a market for corporate ownership led to aggressive takeovers and asset-stripping, as exemplified by the manoeuvres of wealthy industrialists such as Lord Hanson. In this case the kind of market involved, so far from « failing », worked all too well.

\subsubsection{Sectoral systems}

The literature on sectoral systems of innovation has not yet been able to demarcate clear boundaries for what it embraces by each sector - usually falling back on OECD definitions of "industries », which are an inconsistent mixture of product-based and technology-based categories. Yet the work of Malerba (2005) and colleagues has adduced the main drivers of such « systems », as summarised here under four sub-headings.

a) Opportunity: most concern has been expressed in this connection as relating to technological opportunities, of the kinds already outlined, though as ICTs became general-purpose in nature they lost their sector-specific identities. Market opportunities would seem to be more applicable to the given context of product-oriented sectors, and here the British situation was varied. There seems to be some agreement in the literature that government ownership and regulation of the National Health Service benefited the growth of the UK pharmaceutical industry through its stability, whereas frequent changes induced by erratic governmental decision-making proved disruptive in some other high-tech markets (like nuclear power). In geographical terms, British producers have been criticised for restricting their exports largely to safe Empire and Commonwealth markets (e.g. Owen, date, for motor vehicles).

b) Appropriability: here the issues have tended to focus on patenting, or rather the lack of it (as the statistics previously cited demonstrate), by many British companies and other organisations. It is widely believed, for instance, that British success in patenting of pharmaceuticals boosted financial support for that industry. However it is conceivable that British companies were better at developing « dynamic » modes of appropriability such as lead time, than at «static» modes such as patenting.

c) Cumulativeness : in this aspect the issues focused on matters of size and concentration. We have already observed how the 1960s and 70s witnessed a quest for large corporations able to exert monopolistic muscle through becoming « national champions ». This effort rather disintegrated thereafter as 
forces of globalization demanded the rise of « international champions », leaving the old national monopolies stranded. Moreover, countervailing forces to do with anxieties about innovation, employment, autonomy, etc., appeared to warrant support for SMEs. Since the assessment by Kamien and Schwartz (1982), analysts have learnt to distinguish between matters of size and matters of concentration. Indeed, in the UK case, there is some evidence from admittedly rather confused data suggesting that both small and large firms may be best for innovation (e.g. Pavitt et al., 1987, based on the SPRU innovation database for 1945-83), but medium levels of concentration could be best, to avoid the contrasting inefficiencies of lack of power in fragmented industries and lack of incentives in monopolistic industries.

d) Knowledge base : there were belated concerns about declining numbers in STEM subjects (science, technology, engineering, mathematics), though attempts to solve the problem through government intervention were either inadequate - in the sense of having little visible impact - or excessive, as students were lured into fields such as « computer studies » in the later 1990s and early 2000 s, only to find that the jobs to employ them were no longer present.

The sectoral data provided in von Tunzelmann (2003) support many of the above findings, both positively and negatively. For the UK, the figures indicate a squeeze on R\&D in high-tech sectors apart from pharmaceuticals - most evident in sectors like aerospace (facing some withdrawal of protected home markets as the government cut its defence budgets) and electronics (loss of innovative competitiveness), despite the production shares of the UK holding up in these sectors. The implication was one of a loss of power to foreignbased MNCs that took over much of the UK production.

Even more significant is the fact that these figures overlook the rising share of R\&D in services, amounting to maybe as much as one-quarter of the total by the later 1990s (Boden, 1998). The report from NESTA (2006) dwells on the importance of many service sectors to the UK economy, and the comparative unimportance of traditionally measured $R \& D$ in those sectors, though even here some impact has become evident. Whether the UK success in financial services outlives the current financial crisis remains to be seen.

\section{III. - THE PUBLIC SECTOR AND TECHNOLOGY POLICY}

\subsection{The early postwar period}

Technology was envisaged by postwar governments as part of world advancing at the macro level through combination of Keynesian rationalism, partnership with both industry and trade unions, and mass education (Buxton et al., 1998). The counterpart at the meso level was investment in technologically advanced manufacturing, and at the micro level of (static) economies of scale. These, as already observed, were seen to be achieved through fostering 
large corporations, often with monopolistic control in the guise of the «national champions ».

In fact no postwar government really succeeded in integrating all these components with technology in systemic fashion. There was at best a half-hearted attempt at the Ministry of Technology under Harold Wilson, but this ministry was chronically underfunded and lacked adequate political clout. In practice, attempts to forge any systemic response were outflanked by changing technological and economic paradigms (e.g. the breakdown of the Bretton Woods agreements in the late 1960s, or the rise of MNCs under globalisation). As macroeconomic policies appeared to fail, industrial policy came to be increasingly directed at supporting « lame duck» firms and industries, rather than setting the technological basis for a different future.

\subsection{The middle years}

The new UK policy agenda for the 1980s tried to encourage deregulation, privatization and « enterprise »- justified as representing « working with the grain of market forces ... [assisting firms] without weakening their commercial responsibility for their own actions » (Barber and White, 1987 : 26), and evidently preferable to working against the grain of market forces as in the « lame ducks » strategies of the 1970s. This, however, led to policy «by default », of letting market and corporate failures take their own course towards destruction - contrasting sharply with the reality (though not the rhetoric) of US policy in the later 1980s (Branscomb and Keller, 1998).

Any government money for these purposes had to be justified on grounds of « market failure » (the market sector would not do such things unaided), « additionality » (government money could not simply replace private expenditures), and especially of being " pre-commercialization » research. Thus, according to a calculation by (Baroness) Margaret Sharp, industrial subsidies were cut from about $£ 20$ b in the late 1970 s to just $£ 0.5$ b by the late 90 s (both measured in 1996 prices) (cited in Barber and Georghiou, forthcoming: 2).

Technology policy reached something of an impasse, as the new collaborative ventures set up even in the early 1980s were wound down, in a new vogue for « enterprise » as well as for « rolling back the state ». In practice, what this often meant was expanding the role for private-sector consultancy, funded if need by the government, in lieu of leadership by the state. The most serious case in point was the "Alvey programme » to support fledgling developments in the UK's ICT sector, which although being highly ranked in evaluations by outside experts in its first phase (1983-87), also fell victim to the cuts and diversions of public expenditures into the pockets of consultants thereafter.

More generally, the policy stances adopted in these years can be seen as including the following: 
a) A shift from « mission » towards « diffusion » in the orientation of policies, to adopt the terminology of Ergas (1987), who had found the execution of such mission orientation weaker in the UK than in other primarily missionfocused countries like France or the USA.

b) Despite this a level of expenditure on military R\&D that continued to be high, still some $36 \%$ of total GERD as late as 1997/8 despite the ending of the « Cold War » at the start of the 1990s. Military R\&D was characterised by its resort to " baroque » technologies (Kaldor, 1982), increasingly limiting its « dual-use » functionality for take-up by the civilian sector, e.g. in electronics.

c) The relentless privatization of nationalised industries cut $R \& D$ expenditures, which tended to be regarded as « wasteful » from a short-term commercial standpoint.

d) Regulatory issues were compounded by governance problems, for instance in response to rising public awareness of environmental concerns, moving ahead of governmental action. Public support for science was shaken by a succession of scandals, especially in the area of food policy, where the role of the existing ministry (MAFF, the Ministry for Agriculture, Fisheries and Food) was coming to be seen as deeply ambiguous - MAFF was replaced by DEFRA (the Department for the Environment, Food and Rural Affairs).

\subsection{Policy design in later years}

« Policy design » represents the ways in which multiple layers of systems are individually and collectively structured and controlled to yield benefits - good policy design is, in part, the expression of a satisfactory alignment process. With this in mind, Freitas and von Tunzelmann (2008) test a three-dimensional model of public support design - vertical/horizontal knowledge objectives, specific/general support provided, and local/central implementation - as a framework to characterise and compare national policy incentives. The paper compares 149 policy programmes in the UK and France from the early 1980s to 2002 .

Despite the two countries having different national innovation systems, the role of policy-making in both became increasingly recognised as a provider of market incentives to new and/or better business-to-business services markets. Both the French and the British public business supports became more nonfinancial each time policy was redesigned, and increasingly concerned with innovation. More specifically, until the mid-1990s, the French portfolio of innovation policies concentrated more on the use of local support frameworks and local services structures, while the British showed a greater reliance on label creation (setting quality standards etc.) and central financial subsidies.

In the UK, the introduction of value-for-money and « hands-off policy execution » principles in the public sector delayed the process of decentralisation 
of public business support - before the mid-1990s most horizontal public support consisted of specific types of support centrally delivered, but from the mid-90s a change can be observed towards more local implementation and the provision of general support. It is also worth observing that, at least in our dataset, most of the British programmes do not last for more than one sub-period - on the contrary, most of the French programmes launched in the first (1980/88) and second (1989/94) sub-periods were still active in the final period (1999/2003). Whether this implies a lesser stability in British policymaking or a greater willingness to take on new challenges (or both) must remain for others to assess.

\section{IV. - DISCUSSION : THE ROLE OF INTERACTIVE AND DYNAMIC CAPABILITIES IN POLICY-MAKING}

In complex structures such as national innovation systems, there is no a prio$r i$ guarantee that the capabilities of one type of agent (say firms) evolve in the same direction as those of another type of agent (say household consumers). First, in accord with a classic market failure issue, asymmetries of information may take them in different directions. But second, and more broadly, « asymmetries of knowledge » may prevent them from going in the same directions, even under the supposition that both parties are blessed with perfect information.

Without going so far as to presume the existence of perfect information, the significance of such asymmetries of knowledge is enough to propose that interaction among the relevant types of agents may be necessary, whether $e x$ ante, through knowledge exchanges, or ex post, through market exchanges. Thus a typical motor vehicle assembler engaged in contracting out the manufacture of individual components to its suppliers will usually begin with a phase of knowledge interaction between them to settle details relating to the parts in question, before purchasing those parts through market mechanisms the assembler will already have resolved the matter of quality control etc. before paying for the items delivered.

Different agents (whether they are different firms or - say - different levels of government) have differing capabilities for interaction - the ability to learn from such interaction and to absorb the lessons, and then to « recycle » their products into the system. In the case of governments, the «products » we are concerned with are policies and their design. In the same manner as firms (and universities), governments have differing competencies and dynamic capabilities to react to and direct change, as exemplified by the crucial role of « vision » in East Asian governments (von Tunzelmann et al., forthcoming).

The prevailing context of what Schumpeter (1934:64) called «dynamic competition » means the environment (landscape) may be constantly changing. This entails interaction of the kinds hinted at above occurring in « real time ». The extent to which the interactive capabilities of governments are 
« dynamic » is therefore dependent on the degree to which their policy sources and/or impacts are not only novel but also appropriate to the changing environments in which they are positioned. Formally speaking, government's dynamic interactive capabilities represent the extent to which the change in its capabilities influences or is influenced by the change in the capabilities of policy « suppliers » and users, all in real time.

Expressing such dynamic interactive capabilities in policy-making implies the need to operate through demand as well as supply factors, including the appropriate deployment of macroeconomic policy. In my paper in Revue d'Économie Industrielle I therefore argued that governments should move towards a «Schumpeterian macroeconomics » (von Tunzelmann, 2004), involving the active use of macro demand expansion to encourage demandpull innovation. I contended that in theoretical as well as practical terms this would overcome the shackle of a vertical aggregate supply curve as argued by monetarist economists.

To achieve this outcome implies in addition a need to enhance interactivity. In recent times this has led policy-makers to advocate approaches that involve support for « clusters » - a view promoted further by the influence of advisers such as Michael Porter (Porter and Ketels, 2003). While these can help with the interactive side of the coin, they can be a sometimes hindering element as regards the pressure to act dynamically, since the notion of a cluster is inherently static. The dynamic counterpart of the cluster is indicated by the concept of a « regional system of innovation », designed to promote interactivity for change occurring in "real time ». Unfortunately the Regional Development Agencies (RDAs) set up to divide the country with this in mind in 1999 have lacked an adequate knowledge base for effective policy-making (Barber and Georghiou, forthcoming).

The key issue comes back to a need to « align » the objectives of all types of actors and agents. In other words, I am claiming that the underlying source of policy inadequacy remains a matter of «network failure » through misalignments. There is a need at governmental level to « align » the micro, meso and macro levels, which may involve positive interactions between as well as within local, regional, national and global systems of innovation. There is an associated need - as the defensible but underwhelming resort to RDAs shows - to inculcate policy capabilities to make the desired connections, through " policy learning » (both internally within each government organization, and externally through interacting with experts, evaluators, etc.).

\section{V. - CONCLUSIONS}

The UK White Paper of 1988 (Cmnd 278) ended most support for singlecompany $R \& D$ and placed its emphasis on collaborative $R \& D$, yet the underpinning economic analysis retreated deeper into the mystique of « market failure ». 
While it is sometimes possible to impute market-related costs to the fundamental shortcomings of policy-making noted in this paper, this does not mean that providing a market would have resolved the problem identified. Often, indeed, it might have exacerbated it, as with recent financial problems, or with the «market for corporate control» (through encouraging myopic behaviour).

Instead, the paper sees the basic failings as being network failures in inadequate collaboration, and "inter-systemic » failures of breakdowns between national «systems » of science, industrial innovation, finance, workplace organization, etc. (von Tunzelmann, 2003) - in other words, alignment failures. These breakdowns in turn gave rise to a «blame culture » from mutual misunderstandings, for example as between the « separate spheres » of finance and manufacturing industry. The resort to middlemen consultants did little, in that such people were not trusted by SMEs (Barber and Georghiou, forthcoming). Meanwhile, the rather incongruous adherence to the « linear model » involved a reliance on academic spin-offs for generating new technologies and also their diffusion. The split of the old DTI into the newly created departments called DIUS (for science and long-term technology development) and BERR (for business innovation) in 2007, if anything, looks likely to perpetuate the inter-systemic failures that have characterised British technological development for over a century.

In this paper I have thus argued firstly that an analysis of technology trends indicates that non-market failures, mainly systemic and dynamic in nature, were a more basic source of British technological shortcomings than market failures. Secondly, an analysis of trends in UK technology policy has suggested that narrowly economics-based views too often hampered good intentions to reform policy along more appropriate lines, and restricted development of any serious capabilities for « policy learning » in relation to innovation by UK governments both national and regional. While no country probably gets all the relevant networks fully aligned to achieve optimal output, the argument here is that the UK could gain from adopting « better practice » approaches to improve its innovative performance.

\section{REFERENCES}

AKERLOF G.-A. (1970), "The market for "lemons": quality uncertainty and the market mechanism », Quarterly Journal of Economics, 84: 488-500.

ARROW K.-J. (1962), « Economic welfare and the allocation of resources for innovation », in Nelson R.-R. (ed.), The Rate and Direction of Inventive Activity, NBER/Princeton University Press, Princeton NJ, pp. 609-626.

BARBER J. and WHITE G. (1987), « Current policy practice and problems from a UK perspective », in Dasgupta, P. and Stoneman, P. (eds), Economic Policy and Technological Performance, Cambridge University Press, Cambridge, pp. 24-50.

BARBER J. and GEORGHIOU L., forthcoming, « Developments in UK technology and innovation policy and the formulation of policy rationales », mimeo draft, July 2008.

BODEN M. (1998), « Science and technology in the private sector », in Cunningham, P. (ed.), Science and Technology in the United Kingdom, $2^{\text {nd }}$ ed., Cartermill International, London. 
BRANSCOMB L.-M. and KELLER J. (eds), (1998), Investing in Innovation : creating a research and innovation policy that works, MIT Press, Cambridge MA.

BUXTON T., CHAPMAN P. and TEMPLE P. (eds), (1998), Britain's Economic Performance, $2^{\text {nd }}$ ed., Routledge, London.

CHANDLER A.-D. jr., AMATORI F. and HIKINO T. (eds), (1999), Big Business and the Wealth of Nations, Cambridge University Press, Cambridge.

DIEDEREN P., STONEMAN P., TOIVANEN O. and WOLTERS A. (1999), Innovation and Research Policies : an international comparative analysis, Edward Elgar, Cheltenham.

ERGAS H. (1987), « The importance of technology policy », in Dasgupta P. and Stoneman P. (eds), Economic Policy and Technological Performance, Cambridge University Press, Cambridge, pp. 51-96.

FREEMAN C. and PEREZ C. (1988), « Structural crises of adjustment, business cycles and investment behaviour », in Dosi G., Freeman C., Nelson R., Silverberg G. and Soete L. (eds), Technical Change and Economic Theory, Pinter, London, pp. 38-66.

FREITAS I.-M.-B. and von TUNZELMANN N. (2008), « Mapping public support for innovation: a comparison of policy alignment in the UK and France », Research Policy, 37: 14461464.

GEORGHIOU L. (2001), « The United Kingdom national system of research, technology and innovation », in Larédo P. and Mustar P. (eds), Research and Innovation Policies in the New Global Economy: an international comparative analysis, Edward Elgar, Cheltenham.

GIULIANI E. (2007), « Towards an understanding of knowledge spillovers in industrial clusters », Applied Economics Letters, 14: 87-90.

GRANSTRAND Ö., PATEL P., PAVITT K. (1997), « Multi-technology corporations: why they have "distributed" rather than "distinctive core" competencies », California Management Review, 39: 8-25.

GUMMETT P. (1991), « History, development and organisation of UK science and technology up to 1982 », in Nicholson R., Cunningham C.M. and Gummett P. (eds), Science and Technology in the United Kingdom, Longman, Harlow.

HENDERSON P.-D. (1977), « Two British errors: their probable size and some possible lessons », Oxford Economic Papers, 29: 159-205.

KAMIEN M.-I. and SCHWARTZ N.-L. (1982), Market Structure and Innovation, Cambridge University Press, Cambridge MA.

KORNAI J. (1980), Economics of Shortage, North-Holland, Amsterdam.

LARSEN M.-T. and von TUNZELMANN N. (2008), « When non-markets fail: the role of public science in the development of generic technology », in Cañibano C., Encinar M.-I. and Muñoz F. (eds.), Economía del Conocimiento y la Innovación: nuevas aproximaciones a une relación compleja, Ediciones Pirámide, Madrid (in Spanish).

LEE T.-L. and von TUNZELMANN N. (2005), «A dynamic analytic approach to national innovation systems: the IC industry in Taiwan », Research Policy, 34: 425-440.

MALERBA F. (ed.), (2005), Sectoral Systems of Innovation: concepts, issues and analyses of six major sectors in Europe, Cambridge University Press, Cambridge.

MAY R. (1997), " The scientific wealth of nations », Science, 275: 793-6.

NELSON R.-R. (1959), "The simple economics of basic scientific research », Journal of Political Economy, 67: 297-306.

NESTA (2006), The Innovation Gap : why policy needs to reflect the reality of innovation in the $U K$, NESTA, London.

NESTA (2007), Hidden Innovation: how innovation happens in six «low innovation » sectors, NESTA, London.

NESTA (2008), Total Innovation: why harnessing the hidden innovation in high-technology sectors is crucial to retaining the UK's innovation edge, NESTA, London.

OWEN G. (1999), From Empire to Europe : the decline and revival of British industry since the second world war, London, Harper Collins, 1999.

PATEL P. and PAVITT K. (1988), « The international distribution and determinants of technological activities », Oxford Review of Economic Policy, 4: 81-99.

PAVITT K. (ed.), (1980), Technical Innovation and British Economic Performance, Palgrave Macmillan, London.

PAVITT K., ROBSON M. and TOWNSEND J. (1987), « The size distribution of innovating firms in the UK, 1945-1983 », Journal of Industrial Economics, 35 : 297-316. 
PORTER M.-E. and KETELS C.-M. (2003, « UK competitiveness : moving to the next stage », DTI Economics Paper, $\mathrm{n}^{\circ}$ 3, May.

PRAKASH A. and HART J.-A. (eds), (1999), Globalization and Governance, Routledge, London \& New York.

RICHARDSON G.-B. (1972), « The organisation of industry », Economic Journal, 82: 883896.

RICHARDSON G.-B. (2008), « What I learned, as an economist, from managing a business », paper to REI workshop, Juan-les-Pins, Nov.

ROMER P.-M. (1986), «Increasing returns and long-run growth », Journal of Political Economy, 94: 1002-1037.

ROMER P.-M. (1990), « Endogenous technological change », Journal of Political Economy, 98 : S71-S102.

ROMER P.-M. (1994), « The origins of endogenous growth », Journal of Economic Perspectives, 8: 3-22.

SEN A.-K. (1985), Commodities and Capabilities, North-Holland, Amsterdam.

SCHUMPETER J.-A. (1934), Theory of Economic Development : an inquiry into profits, capital, credit, interest, and the business cycle, Harvard University Press, Cambridge MA.

THOMPSON G., FRANCES J., LEVACIC R. and MITCHELL J.-C. (eds), (1991), Markets, Hierarchies and Networks: the coordination of social life, Sage/Open University, London.

UK Government (1988), DTI - the Department for Enterprise, White Paper (Cmnd 278) (http://www.boperis.ac.uk/imgall/ref20518_1_1.html).

van ZWANENBERG P. and MILLSTONE E. (2005), BSE: Risk, Science, and Governance, Oxford University Press, Oxford.

von TUNZELMANN N. (1999), "Growth and the supply side in Europe since the Second World War », in Dyker, D.-A. (ed.), The European Economy, 2nd ed., Longman, London, pp. 11-42.

von TUNZELMANN N. (2003), « Technology in post-war Britain », in Floud R. and Johnson P. (eds), The Cambridge Economic History of Modern Britain, volume III : structural change and growth, 1939-2000, Cambridge University Press, Cambridge, pp. 299-331.

von TUNZELMANN N. (2004), "Integrating economic policy and technology policy in the EU », Revue d'Économie Industrielle, $\mathrm{n}^{\circ}$ 105: 85-104.

von TUNZELMANN N., BOGDANOWICZ M. and BIANCHI A. (eds), The New Dynamics of Growth and Change in Asia, World Scientific Publishing, Singapore, 2009.

ZIMAN J. (1987), Science in a "steady state »: the research system in transition, Science Policy Support Group, London. 